Abstracta Iranica Abstracta Iranica

Revue bibliographique pour le domaine irano-aryen

Volume 34-35-36 | 2017

Comptes rendus des publications de 2011-2013

\title{
Werner Sundermann, Almut Hintze, François de Blois (eds.). Exegisti monumenta. Festschrift in Honour of Nicholas Sims-Williams
}

Philip Huyse

\section{(2) OpenEdition}

Journals

Édition électronique

URL : http://journals.openedition.org/abstractairanica/42000

DOI : 10.4000/abstractairanica.42000

ISSN : 1961-960X

Éditeur :

CNRS (UMR 7528 Mondes iraniens et indiens), Éditions de l'IFRI

Référence électronique

Philip Huyse, « Werner Sundermann, Almut Hintze, François de Blois (eds.). Exegisti monumenta. Festschrift in Honour of Nicholas Sims-Williams », Abstracta Iranica [En ligne], Volume 34-35-36 | 2017, document 4, mis en ligne le 30 juillet 2017, consulté le 02 octobre 2020. URL : http://

journals.openedition.org/abstractairanica/42000; DOI : https://doi.org/10.4000/abstractairanica. 42000

Ce document a été généré automatiquement le 2 octobre 2020.

Tous droits réservés 


\title{
Werner Sundermann, Almut Hintze, François de Blois (eds.). Exegisti monumenta. Festschrift in Honour of Nicholas Sims-Williams
}

\author{
Philip Huyse
}

\section{RÉFÉRENCE}

Werner Sundermann, Almut Hintze, François de Blois (eds.). Exegisti monumenta.

Festschrift in Honour of Nicholas Sims-Williams. Wiesbaden, Harrassowitz Verlag, 2009, XL + 596 p. (Iranica, herausgegeben von Maria Macuch, Band 17)

1 A l'occasion de son soixantième anniversaire, Werner Sundermann, Almut Hintze et François de Blois, ont édité ce très beau et volumineux recueil en l'honneur de l'iraniste britannique Nicholas Sims-Williams. En l'espace de quatre décennies, celui-ci a produit une impressionnante série de contributions d'une rare qualité sur des sujets divers et variés dans les domaines du bactrien - dont il a immensément fait progressé la connaissance -, de la paléographie et de la grammaire sogdiennes, ainsi que d'autres langues du moyen-iranien oriental. En début du volume, les éditeurs dressent un portrait touchant de ce grand savant (p. XIII-XXIV) et joignent une liste particulièrement bienvenue des "Publications of Nicholas Sims-Williams" (p. XXVXXXVIII).

Le volume comprend quarante articles, dont voici la liste : A. D. H. Bivar, "The Rukhkh, Giant Eagle of the Southern Seas" (p. 1-12). François de Blois, "A Sasanian Silver Bowl" (p. 13-16). Alberto Cantera, "On the History of the Middle Persian Nominal Inflection" (p. 17-30). Carlo G. Cereti, "The Pahlavi Signatures on the Quilon Copper Plates (Tabula Quilonensis)" (p. 31-50). Johnny Cheung, "Two Notes on Bactrian" (p. 51-58). Iris Colditz, "The Parthian 'Sermon on happiness' (Hunsandïft wifrās)" (p. 59-93). Josef 
Elfenbein, "Eastern Hill Balochi” (p. 95-104). Harry Falk, "The Name of Vema Takhtu" (p. 105-16). Philippe Gignoux, "Les relations interlinguistiques de quelques termes de la pharmacopée antique. II" (p. 117-26). Jost Gippert, “An Etymological Trifle” (p. 127-40). Gherardo Gnoli, "Some Notes upon the Religious Significance of the Rabatak Inscription" (p. 141-59). Frantz Grenet, "The Pahlavi Text Māh ī Frawardīn rōz ì Hordād. A Source of Some Passages of Bīrūnī's Chronology" (p. 161-70). Almut Hintze, "Disseminating the Mazdayasnian Religion. An Edition of the Avestan Hērbedestān Chapter 5" (p. 171-90). Erica C. D. Hunter, “A Jewish Inscription from Jām, Afghanistan" (p. 191-96). Agnes Korn, "Lengthening of $i$ and $u$ in Persian" (p. 197-213). Judith A. Lerner, "Animal Headdresses on the Sealings of the Bactrian Documents" (p. 215-26). Samuel N. C. Lieu, "Epigraphica Nestoriana Serica” (p. 227-46). Vladimir A. Livshits, "Sogdian Gems and Seals from the Collection of the Oriental Department of the State Hermitage" (p. 247-50). Maria Macuch, "Disseminating the Mazdayasnian Religion. An Edition of the Pahlavi Hērbedestān Chapter 5" (p. 251-77). Mauro Maggi, "Hindrances in the Khotanese Book of Vimalakïrti" (p. 279-92). Dieter Maue, "Einige uigurische Wörter indischen und iranischen Ursprungs" (p. 293-311). Barbara Meisterernst, Desmond Durkin-Meisterernst, "The Buddhist Sogdian P 7 and its Chinese Source” (p. 313-24). Enrico Morano, “'If they had lived ...'. A Sogdian-Parthian Fragment of Mani's Book of Giants" (p. 325-30). Antonio Panaino, "The Bactrian Royal Title $\beta \alpha \gamma[\eta]-\zeta v o \gamma o ~ / ~ \beta \alpha \gamma o-$ inלvoyo and the Kušān Dynastic Cult" (p. 331-46). Elio Provasi, "Versification in Sogdian" (p. 347-68). Christiane Reck, "The Ascension of the Light Elements and the Imprisonment of Ahriman. The Cosmogonical and Eschatological Part of a Sogdian 'Sammelhandschrift"' (p. 369-98). Rong Xinjiang, "Further Remarks on Sogdians in the Western Regions" (p. 399-416). Rüdiger Schmitt, "Bemerkungen zu susischen DareiosInschriften, vornehmlich auf Glasurziegeln" (p. 417-28). Martin Schwartz, "Pouruchista's Gathic Wedding and the Teleological Composition of the Gathas" (p. 429-47). Shaul Shaked, "Classification of Linguistic Features in Early Judeo-Persian Texts" (p. 449-61). Patrick Sims-Williams, “Celto-Iranica" (p. 463-67). Ursula SimsWilliams, "Behind the Scenes: Some Notes on the Decipherment of the Sogdian Manuscripts in the Stein Collection" (p. 469-78). Prods Oktor Skjærvø, “OL' News: ODs and Ends" (p. 479-95). Werner Sundermann, "Ein manichäischer Traktat über und wider die Christen" (p. 497-508). Elizabeth Tucker, "Old Iranian Superlatives in -išta-" (p. 509-26). Étienne de la Vaissière, "The Triple System of Orography in Ptolemy's Xinjiang” (p. 527-35). Dieter Weber, “A Pahlavi Letter from Egypt Re-visited (P. 44)” (p. 537-50). Ehsan Yarshater, "Four Tati Sub-Dialects" (p. 551-70). Yutaka Yoshida, “TurcoSogdian features" (p. 571-85). Peter Zieme, “Die Preisung des Lichtreichs nach einem alttürkischen Fragment in London" (p. 587-96).

\section{AUTEURS}

\section{PHILIP HUYSE}

EPHE 